Vol. 1, No. 2 Maret 2016 - Halaman 1 s.d 13

\title{
PENGARUH FREE CASH FLOW DAN LEVERAGE TERHADAP HARGA SAHAM DENGAN KEBIJAKAN DIVIDEN SEBAGAI VARIABEL INTERVENING
}

\author{
G. A. Sri Oktaryani, Siti Sofiyah, I Nyoman Nugraha A.P., \\ I Dewa Gde Bisma, I Gede Mandra
}

\begin{abstract}
ABSTRAK
Penelitian ini bertujuan untuk mengetahui pengaruh free cash flow dan leverage terhadap harga saham dengan menggunakan kebijakan dividen sebagai variabel intervening, dimana kebijakan dividen diproksikan dengan dividend payout ratio (DPR). Penelitian ini menggunakan pendekatan kuantitatif dan analisis dilakukan menggunakan metode analisis jalur (path analysis). Sampel penelitian diambil dari industri manufaktur di Bursa Efek Indonesia (BEI) selama kurun waktu 2010 - 2014 dengan metode purposive sampling. Diperoleh 16 perusahaan sebagai sampel, yang diobservasi selama 5 tahun dengan total observasi sebanyak 80. Hasil penelitian menunjukkan bahwa free cash flow dan leverage memiliki pengaruh langsung yang signifikan terhadap harga saham. Pengaruh langsung free cash flow terhadap kebijakan dividen adalah signifikan, sedangkan leverage tidak berpengaruh terhadap kebijakan dividen. Hasil penelitian juga menunjukkan bahwa kebijakan dividen tidak dapat memediasi pengaruh free cash flow dan leverage terhadap harga saham.
\end{abstract}

Kata kunci: free cash flow, leverage, harga saham, kebijakan dividen.

\section{PENDAHULUAN}

Dalam manajemen keuangan, tujuan utama perusahaan adalah untuk memaksimumkan kemakmuran pemegang saham. Tujuan tersebut dapat diwujudkan dengan memaksimumkan nilai perusahaan (Brigham dan Houston, 2006). Untuk memaksimumkan nilai perusahaan, manajer membuat tiga keputusan utama, yaitu keputusan pendanaan, keputusan investasi dan kebijakan dividen. Secara umum nilai perusahaan tercermin dari harga saham perusahaan yang terus meningkat. Sehingga semakin tinggi harga saham, maka makin tinggi juga nilai perusahaan. Shiller (1987) dalam Zakaria et al. (2012) menyatakan bahwa perubahan atau volatilitas harga saham dipengaruhi oleh faktor-faktor psikologis. Faktor-faktor tersebut diantaranya adalah reaksi berlebihan investor atas pengumuman dividen atau berita lainnya, gelombang optimisme atau pesimisme sosial serta tren saat ini.

Informasi yang terkandung dalam free cash flow memiliki nilai informasi yang dapat mempengaruhi pergerakan saham itu sendiri. Menurut Jensen dan Meckling (1976) dalam Atmaja (2008) menyatakan bahwa keberadaan free cash flow dapat menimbulkan masalah keagenan yang disebabkan perbedaan kepentingan antara pemegang saham dan manajer. Free cash flow mencerminkan fleksibilitas perusahaan dalam melakukan investasi tambahan, melunasi hutang, membeli saham treasury atau menambah likuiditas. Sehingga free cash flow yang tinggi 
mengindikasikan kinerja perusahaan yang tinggi. Kinerja dari perusahaan yang tinggi akan meningkatkan nilai pemegang saham yang diwujudkan dalam bentuk return yang tinggi melalui perkembangan harga saham, dividen ataupun laba ditahan untuk diinvestasikan di masa depan (Arieska dan Gunawan, 2011). Penelitian Embara dkk.(2012) yang menunjukkan pengaruh positif antara free cash flow terhadap kebijakan dividen. Sedangkan penelitian lainnya yang dilakukan oleh Parsian dan Koloukhi (2014) mengungkapkan bahwa free cash flow berpengaruh negatif terhadap kebijakan dividen.

Safkaur (2015) mengemukakan bahwa untuk mengurangi biaya keagenan, beberapa alternative dapat dilakukan. Diantaranya adalah dengan meningkatkan Dividend Payout Ratio (DPR) dan debt-financing. Dalam menjalankan kegiatan operasionalnya, perusahaan membutuhkan pendanaan yang bisa berasal dari sumber internal dan eksternal. Rasio leverage menunjukkan proporsi pendanaan yang bersumber dari hutang dan ekuitas. Demi memaksimumkan nilai perusahaan, manajer perlu membuat keputusan pendanaan yang optimal. Keputusan tersebut idealnya memberikan tingkat keuntungan yang tinggi sehingga pasar merespon keputusan tersebut secara positif guna meningkatkan harga saham perusahaan. Penelitian yang dilakukan oleh Mardasari (2014), Rizqia dkk. (2013) serta Wati dan Darmayanti (2012) mengungkapkan adanya pengaruh dari debt to equity ratio (DER) terhadap nilai perusahaan.

Kebijakan Dividen merupakan salah satu dari keputusan utama yang harus diambil oleh manajer untuk meningkatkan nilai perusahaan. Dividend Signaling Model yang dikemukakan oleh Bhattacharya (1979) dalam Embara dkk. (2012) merupakan salah satu model yang mendasari dugaan bahwa pengumuman perubahan dividen tunai mempunyai kandungan informasi yang mengakibatkan adanya reaksi harga saham. Model ini menjelaskan bahwa informasi tentang perubahan yang dibayarkan digunakan oleh investor sebagai sinyal tentang prospek perusahaan di masa yang akan datang. Pemegang saham akan menginterpretasikan peningkatan pembayaran dividen oleh perusahaan, sebagai sinyal bahwa pihak manajemen memiliki prediksi arus kas yang tinggi dimasa yang akan datang. Penurunan pembayaran dividen diinterpretasikan sebagai antisipasi manajer terhadap terbatasnya arus kas dimasa yang akan datang.

Pembayaran dividen dalam bentuk kas merupakan arus kas keluar, sehingga perusahaan yang memiliki free cash flow yang besar (posisi kas yang kuat) akan mampu menyediakan pembayaran dividen kepada pemegang saham. Posisi kas yang benar-benar tersedia bagi para pemegang saham akan tergambar pada free cash flow yang dimiliki oleh perusahaan. Kallapur (1994) dalam Embara dkk.(2012) menemukan hubungan positif antara aliran kas bebas dengan kebijakan pembayaran dividen. Hal ini sejalan dengan hasil penelitian Embara dkk.(2012) yang menunjukkan pengaruh positif antara free cash flow terhadap kebijakan dividen.

Penelitian Mahaputra dan Wirawati (2014) menunjukkan bahwa Debt to Equity Ratio berpengaruh signifikan terhadap Dividend Payout Ratio. Riyanto (2001) menyatakan apabila perusahaan menentukan bahwa pelunasan hutang diambil dari laba ditahan, maka perusahaan harus menahan sebagian besar pendapatan dari aktivitas operasionalnya untuk keperluan membayar hutang tersebut, yang berarti hanya sebagian kecil saja yang pendapatan yang dapat dibayarkan sebagai deviden. Menurut Sartono (2001) Debt to Equity Ratio (DER) merupakan rasio yang mengukur seberapa jauh perusahaan dibiayai oleh hutang, dimana semakin tinggi 
Vol. 1, No. 2 Maret 2016 - Halaman 1 s.d 13

rasio ini menunjukkan gejala yang kurang baik bagi perusahaan serta kemungkinan pembayaran dividen rendah.

Perusahaan manufaktur umumnya membutuhkan sumber dana jangka panjang untuk membiayai kegiatan operasionalnya. Sumber pendanaan tersebut berasal dari investasi saham, sehingga pihak manajemen tentunya harus menentukan kebijakan dividen yang tepat agar dapat memberikan sinyal positif bagi investor untuk meningkatkan harga saham perusahaan. Perusahaan manufaktur yang terdaftar di Bursa Efek Indonesia (BEI) terbagi ke dalam tiga sektor, yaitu industri dasar dan kimia, aneka industri dan industri barang konsumsi.

Adanya perbedaan dari hasil penelitian terdahulu mengenai faktor-faktor yang mempengaruhi kebijakan dividen dan harga saham serta teori-teori yang mendukung membuat penelitian lebih lanjut penting untuk dilakukan. Sehingga penelitian ini bertujuan untuk menganalisis pengaruh free cash flow dan leverage terhadap harga saham dengan kebijakan dividen sebagai variabel intervening pada perusahaan manufaktur yang terdaftar di BEI selama periode 2010-2014.

\section{TINJAUAN PUSTAKA}

\subsection{Kajian Teori}

\subsubsection{Teori Keagenan (Agency Theory)}

Jensen dan Meckling (1976) dalam Brigham dan Houston (2006) mengungkapkan bahwa teori keagenan menjelaskan hubungan antara agen (manajer) dan principal (pemegang saham). Hubungan antara agen dan principal biasanya dalam situasi asimetri informasi, dimana agen memiliki lebih banyak informasi dibandingkan principal karena yang menjalankan kegiatan operasional adalah agen (manajer). Di satu sisi, pemegang saham ingin agar manajer bekerja untuk mensejahterakan pemegang saham namun manajer perusahaan bisa saja bertindak sebaliknya. Karena munculnya konflik kepentingan tersebut maka pemegang saham harus mengeluarkan sejumlah biaya yang disebut dengan agency cost untuk melakukan pengawasan secara total terhadap para manajer.

Safkaur (2015) mengemukakan beberapa alternatif untuk mengurangi agency cost:

1. meningkatkan kepemilikan saham di pihak manajemen sehingga manajer akan ikut menanggung kerugian akibat keputusan yang salah;

2. meningkatkan dividend payout ratio sehingga tidak banyak arus kas bebas yang tersisa dan manajer harus mencari sumber pendanaan lain dari pihak ekternal untuk membiayai investasi baru;

3. meningkatkan debt-financing guna mengurangi konflik kepentingan antara pemegang saham dan pihak manajemen;

4. memanfaatkan investor institusional sebagai monitoring agent.

\subsubsection{Signaling Theory}

Signaling Theory adalah suatu tindakan yang diambil pihak manajemen perusahaan untuk memberikan petunjuk atau informasi bagi investor tentang bagaimana manajemen memandang prospek perusahaan (Brigham dan Houston, 2006). Dorongan perusahaan untuk memberikan informasi adalah karena terdapat asimetri informasi antara perusahaan dan pihak luar (khususnya investor dan kreditur). Teori ini menyatakan bahwa investor dapat membedakan antara perusahaan yang memiliki nilai tinggi dengan perusahaan yang memiliki nilai rendah. Perusahaan yang selalu menghasilkan profit memberikan sinyal tentang 
perusahaannya yang relatif tidak mudah mengalami kebangkrutan dan bentuk lain dari financial distress, dibanding perusahaan yang kurang menghasilkan profit.

Penggunaan dividen sebagai isyarat, cenderung berupa cerita bagaimana informasi dapat diteruskan ke pasar. Pengumuman yang menyatakan bahwa suatu perusahaan telah memutuskan untuk menaikkan dividen per saham mungkin diartikan oleh penanam modal sebagai berita yang baik karena dividen per saham yang lebih tinggi menunjukkan bahwa perusahaan yakin arus kas pada masa mendatang akan cukup besar untuk menanggung tingkat dividen yang tinggi (Weston dan Copeland, 1996).

\subsubsection{Dividend Irrelevance Theory}

Menurut Modigliani dan Miller (MM), nilai perusahaan tidak ditentukan oleh besar kecilnya pembagian dividen tetapi ditentukan oleh laba bersih sebelum pajak dan kelas risiko perusahaan. Pernyataan MM ini didasarkan pada beberapa asumsi penting seperti :

a) Pasar modal sempurna dimana semua investor adalah rasional.

b) Tidak ada biaya emisi saham baru jika perusahaan menerbitkan saham baru.

c) Tidak ada pajak.

d) Kebijakan investasi perusahaan tidak berubah.

\subsubsection{Bird in The Hand Theory}

Teori ini dikemukakan oleh Gordon dan Lintner yang menyatakan bahwa kebijakan dividen mempunyai pengaruh positif terhadap harga pasar saham. Artinya, semakin besar dividen yang dibagikan perusahaan, maka semakin tinggi harga pasar saham perusahaan dan sebaliknya semakin sedikit dividen yang dibagikan, maka nilai perusahaan akan menurun. Gordon dan Lintner berpendapat bahwa biaya modal saham akan turun seiring dengan pembayaran dividen dinaikkan karena para investor kurang yakin terhadap penerimaan keuntungan modal (capital gain) yang akan dihasilkan dari laba yang ditahan dibandingkan dengan penerimaan dividen (Brigham dan Houston, 2006).

\subsubsection{Clientele Effect}

Teori ini menyatakan bahwa kelompok (clientele) pemegang saham yang berbeda akan memiliki preferensi yang berbeda terhadap kebijakan dividen perusahaan. Kelompok pemegang saham yang membutuhkan penghasilan pada saat ini lebih menyukai Devidend Payout Ratio (DPR) yang tinggi. Sebaliknya kelompok pemegang saham yang tidak membutuhkan uang saat ini lebih senang jika perusahaan menahan sebagian besar laba bersih perusahaan. Jika ada perbedaan pajak bagi individu maka kelompok pemegang saham yang dikenai pajak tinggi lebih menyukai capital gains karena dapat menunda pembayaran pajak dan kelompok ini lebih senang jika perusahaan membagi dividen yang kecil. Sebaliknya kelompok pemegang saham yang dikenai pajak relatif rendah cenderung menyukai dividen yang besar (Atmaja, 2008).

\subsubsection{Free cash flow}

Free cash flow adalah arus kas yang tersedia untuk didistribusikan kepada kreditur atau pemegang saham setelah perusahaan melakukan semua investasi dalam aktiva tetap dan modal kerja yang seharusnya untuk tetap memertahankan operasional perusahaan secara terus menerus (Brigham dan Houston, 2006). Sehingga dapat dikatakan bahwa free cash flow adalah adanya dana yang berlebih, yang tersedia untuk didistribusikan kepada para pemegang saham, dan keputusan tersebut dipengaruhi oleh kebijakan manajemen. Free cash flow mencerminkan 
Vol. 1, No. 2 Maret 2016 - Halaman 1 s.d 13

keleluasaan perusahaan dalam melakukan investasi tambahan, melunasi hutang, membeli saham treasury atau menambah likuiditas.

Terkadang nilai aliran kas bebas dapat bernilai negatif walaupun laba bersih setelah pajak positif sepanjang tahun. Hal ini disebabkan kas perusahaan tersebut digunakan untuk diinvestasikan pada aset-aset operasionalnya. Hal ini juga mengimplikasikan bahwa perusahaan perlu mengusahakan adanya tambahan dari investor maupun kreditor.

\subsubsection{Faktor-Faktor Yang Mempengaruhi Kebijakan Dividen}

Brigham dan Daves (2004) menyebutkan beberapa faktor yang mempengaruhi keputusan yang terkait dengan kebijakan dividen:

a) Kendala yang mungkin timbul dalam pembayaran dividen antara lain:

- batasan yang timbul dari kontrak hutang;

- dividen bagi pemegang saham preferen;

- ketersediaan kas;

- peraturan yang mengharuskan agar pembayaran dividen tidak melebihi laba ditahan untuk melindungi kreditur;

- aturan perpajakan.

b) Kesempatan investasi yang dimiliki perusahaan.

c) Ketersediaan dan biaya dari sumber modal alternatif.

d) Pengaruh Kebijakan dividen terhadap required rate of return $\left(\mathrm{r}_{\mathrm{s}}\right)$.

Efek dari kebijakan dividen atas required rate of return mungkin terkait dengan:

- keinginan pemegang saham untuk memperoleh pendapatan sekarang versus pendapatan di masa mendatang;

- preferensi pemegang saham atas dividen versus capital gains;

- capital gains lebih menguntungkan dari sisi perpajakan dibandingkan dividen;

- kandungan informasi dari dividen.

Faktor yang berpengaruh tidaklah sama untuk setiap perusahaan, tergantung dari tipe pemegang saham saat ini dan calon investor (possible future stockholders).

\subsubsection{Hubungan Free cash flow, Kebijakan Dividen dan Harga Saham}

Penelitian Embara dkk.(2012) yang menunjukkan pengaruh positif antara free cash flow terhadap kebijakan dividen. Sedangkan penelitian lainnya yang dilakukan oleh Parsian dan Koloukhi (2014) mengungkapkan bahwa free cash flow berpengaruh negatif terhadap kebijakan dividen. Kebijakan dividen dalam penelitian ini berhubungan adalah suatu keputusan perusahaan mengenai berapa besar cash dividend yang harus dibayarkan dan berapa kali dividen tersebut dibayarkan dalam satu tahun. Pembayaran dividen tunai merupakan arus kas keluar, sehingga perusahaan yang memiliki free cash flow yang besar akan mampu menyediakan pembayaran dividen kepada pemegang saham.

Penelitian Wardani dan Siregar (2009) serta mengungkapkan bahwa aliran kas bebas berpengaruh positif terhadap nilai pemegang saham. Tujuan dari organisasi komersial adalah memaksimalkan nilai pemegang saham melalui dividen dan kenaikan harga saham. Sehingga aliran kas bebas yang tinggi mengindikasikan kinerja perusahaan yang tinggi. Kinerja dari perusahaan yang tinggi akan meningkatkan nilai pemegang saham yang diwujudkan dalam bentuk return yang 
tinggi melalui dividen atau laba ditahan untuk diinvestasikan di masa depan. Jensen (1986) dalam Wardani dan Siregar (2009) menyatakan berdasarkan prediksi, harga saham akan meningkat jika perusahaan mem-bayar atau berjanji untuk membayar kelebihan kas yang dimiliki kepada pemegang saham. Dengan kata lain, peningkatan pembayaran dividen dalam bentuk dividen kas akan menghasilkan respon positif pada harga saham dalam jangka pendek.

Kebijakan dividen merupakan salah satu kebijakan yang harus diambil oleh manajer perusahaan. Ross (1977) dalam Embara dkk. (2012) berpendapat bahwa manajer sebagai orang dalam yang mempunyai informasi yang lengkap tentang arus kas perusahaan, akan memilih untuk menciptakan isyarat yang jelas mengenai masa depan perusahaan apabila mereka mempunyai dorongan yang tepat untuk melakukannya. Ross membuktikan bahwa kenaikan pada dividen yang dibayarkan dapat menimbulkan isyarat yang jelas kepada pasar bahwa prospek perusahaan telah mengalami kemajuan. Hal ini sejalan dengan hasil penelitian yang dilakukan oleh Zakaria et al. (2012) serta Rizqia dkk. (2013) yang menyatakan bahwa kebijakan dividen berpengaruh terhadap nilai perusahaan.

\subsubsection{Hubungan Leverage, Kebijakan Dividen dan Harga Saham}

Penelitian yang dilakukan oleh Sutrisno (2001) dalam Mahaputra dan Wirawati (2014) menyatakan bahwa Debt to Equity Ratio berpengaruh signifikan terhadap Dividend Payout Ratio. Perusahaan dengan prospek yang baik, cenderung akan mempergunakan hutang sebagai alternatif untuk memenuhi kebutuhan pembayaran dividen dalam jangka pendek, apabila perusahaan tidak mempunyai dana internal untuk memenuhi dana tersebut.

Peningkatan pendanaan melalui hutang merupakan salah satu alternatif untuk mengurangi biaya keagenan dan kinerja perusahaan menjadi lebih efisien sehingga penilaian investor terhadap perusahaan akan meningkat. Investasi yang dihasilkan dari leverage memiliki informasi yang positif tentang perusahaan di masa yang akan datang, selanjutnya berdampak positif terhadap nilai perusahaan. Perusahaan yang mempunyai dana besar yang berasal dari leverage, dengan kesempatan investasi yang tinggi, maka manajernya akan menggunakan dana tersebut untuk membiayai proyek dengan net present value positif sehingga akan meningkatkan nilai pemegang saham (Arieska dan Gunawan, 2011).

Penelitian yang dilakukan oleh Rizqia dkk. (2013) serta Wati dan Darmayanti (2012) mengungkapkan adanya pengaruh positif dari debt to equity ratio (DER) terhadap nilai perusahaan. Sedangkan Setiabudi dan Agustia (2012) dan Zakaria et al. (2012) menyatakan bahwa kebijakan hutang berpengaruh negatif terhadap nilai perusahaan. Hubungan positif antara leverage dan nilai perusahaan menjelaskan bahwa perusahaan yang memiliki hutang jangka panjang tinggi akan dipandang positif bagi investor. Hal ini karena investor menganggap bahwa perusahaan memiliki kinerja keuangan yang baik sehingga dapat melunasi hutang jangka panjang terhadap kreditur. Namun hutang yang terlalu besar memiliki resiko kegagalan dalam melunasi bunga dan pokok pinjaman terhadap kreditur, sehingga resiko kebangkrutan dapat menurunkan nilai perusahaan (Mardasari, 2014).

Hasil penelitian Mardasari (2014) menunjukkan bahwa kebijakan hutang berpengaruh terhadap nilai perusahaan melalui kebijakan dividen. Tingginya hutang perusahaan sektor manufaktur mengakibatkan menurunnya dividen yang akan dibagikan kepada pemegang saham. Hal ini karena laba yang dihasilkan perusahaan akan lebih banyak digunakan untuk membayar bunga dan pokok pinjaman kepada 
Vol. 1, No. 2 Maret 2016 - Halaman 1 s.d 13

pihak kreditur dibandingkan yang akan dibagikan dalam bentuk dividen kepada pemegang saham. Rendahnya dividen yang akan dibayarkan kepada pemegang saham akan menurunkan nilai perusahaan.

\subsection{Hipotesis}

Berdasarkan kajian teoritis dan empiris maka dapat dirumuskan hipotesis sebagai berikut:

$\mathrm{H}_{1}$ : Free cash flow berpengaruh signifikan terhadap harga saham pada sektor manufaktur di BEI.

$\mathrm{H}_{2}$ : Leverage berpengaruh signifikan terhadap harga saham pada sektor manufaktur di BEI.

$\mathrm{H}_{3}$ : Free cash flow berpengaruh signifikan terhadap kebijakan dividen pada sektor manufaktur di BEI.

$\mathrm{H}_{4}$ : Leverage berpengaruh signifikan terhadap kebijakan dividen pada sektor manufaktur di BEI.

$\mathrm{H}_{5}$ : Kebijakan dividen berpengaruh signifikan terhadap harga saham pada sektor manufaktur di BEI.

$\mathrm{H}_{6}$ : Free cash flow berpengaruh signifikan terhadap harga saham melalui kebijakan dividen pada sektor manufaktur di BEI.

$\mathrm{H}_{7}$ : Leverage berpengaruh signifikan terhadap harga saham melalui kebijakan dividen pada sektor manufaktur di BEI.

\section{METODE PENELITIAN}

Penelitian ini adalah penelitian asosiatif. Penelitian asosiatif merupakan penelitian yang bertujuan untuk mengetahui hubungan antara dua variabel atau lebih. Dengan penelitian ini dibangun suatu teori yang dapat berfungsi untuk menjelaskan, meramalkan dan mengontrol suatu gejala (Sugiyono, 2013).

\subsection{Populasi dan Penentuan Sampel}

Populasi dalam penelitian ini adalah seluruh perusahaan manufaktur yang terdaftar di BEI periode 2010-2014. Sampel dipilih dengan menggunakan teknik purposive sampling dengan tujuan untuk mendapatkan sampel yang sesuai dengan tujuan penelitian. Kriteria perusahaan yang menjadi sampel penelitian adalah: (1) Perusahaan manufaktur yang terdaftar di BEI dan membagikan dividen tunai selama lima tahun berturut-turut selama periode tahun 2010 - 2014; (2) Mempublikasikan laporan keuangan yang telah diaudit selama periode penelitian; (3) Tidak melakukan stock split selama kurun waktu penelitian. Terdapat 16 perusahaan yang memenuhi kriteria sebagai sampel yang diobservasi selama periode $2010-2014$.

\subsection{Jenis dan Sumber Data}

Jenis data yang digunakan dalam penelitian ini adalah data kuantitatif, berupa laporan keuangan dan pergerakan harga saham di sektor manufaktur di BEI selama kurun waktu 2010-2014.

Data dalam penelitian ini merupakan data sekunder yang diperoleh dengan melakukan observasi dan dokumentasi terhadap data yang terangkum dalam ICMD (Indonesian Capital Market Directory) serta dari situs BEI dan situs perusahaan yang dipilih sebagai sampel. Saham-saham yang terpilih sebagai sampel adalah unit observasi dan akan diamati pergerakannya dalam kurun waktu penelitian.

\subsection{Definisi Operasional Variabel}


Variabel dalam penelitian diklasifikasikan menjadi tiga jenis variabel yaitu variabel dependen, variabel intervening dan variabel independen. Variabel dependen adalah harga saham $(\mathrm{Y})$, variabel independen adalah free cash flow $\left(\mathrm{X}_{1}\right)$ dan leverage $\left(\mathrm{X}_{2}\right)$, variabel intervening adalah kebijakan dividen $(\mathrm{M})$. Berikut ini adalah definisi operasional dari variabel-variabel tersebut:

a. Harga Saham adalah harga saham penutupan (closing price) pada akhir tahun.

b. Kebijakan Dividen berkaitan dengan pembagian keuntungan kepada pemegang saham. Apakah laba yang dihasilkan oleh perusahaan akan digunakan untuk membagikan dividen kepada pemegang saham atau dijadikan sebagai laba ditahana. Dalam penelitian ini kebijakan dividen diproksikan dengan Dividend Payout Ratio (DPR) yang menunjukkan perbandingan antara dividen per lembar saham dengan laba per lembar saham. DPR dapat dihitung dengan cara sebagai berikut:

$$
\mathrm{DPR}=\frac{\text { Dividend per share }}{\text { Earning per share }}
$$

c. Free Casm rom mupanar nas uarr kegiatan opersional yang tersedia untuk dibagikan kepada investor termasuk pemegang saham, kreditor dan saham preferen yang dapat dihitung dengan cara mengurangkan laba operasi setelah pajak dengan jumlah investasi pada modal kerja dan aktiva tetap.

FCF $=$ NOPAT + Depreciation - Gross fixed asset expenditures $-\triangle N O W C$

FCF = Free Cash Flow (Arus kas bersih)

NOPAT = Net Operating Profit after Tax (Laba bersih operasi setelah pajak)

$\Delta \mathrm{NOWC}=$ Change in Net Operating Working Capital (Perubahan modal kerja bersih)

d. Leverage menggambarkan bagaimana perusahaan menggunakan hutang untuk mendanai perusahaan sebagai pembiayaan investasi. Dalam penelitian ini leverage diproksikan dengan Debt to Equity Ratio (DER) yang menunjukkan perbandingan antara Total Kewajiban dan Total Ekuitas.

\subsection{Alat Analisis Data}

$$
\text { DER }=\frac{\text { Total Kewajiban }}{\text { Total Ekuitas }}
$$

Suatu variabel disebut mediator atau intervening jika variabel tersebut ikut mempengaruhi hubungan antara variabel eksogen (variable bebas) dan variabel endogen (variable terikat). Untuk mengetahui pengaruh variabel independen (free cash flow dan leverage) terhadap variabel dependen (harga saham) melalui variabel intervening (kebijakan dividen) digunakan metode analisis jalur (path analysis) dengan bantuan IBM SPSS 20. Metode analisis jalur merupakan perluasan dari analisis regresi linier berganda. Hubungan langsung terjadi jika satu atau lebih 
Vol. 1, No. 2 Maret 2016 - Halaman 1 s.d 13

variabel bebas mempengaruhi variabel terikat tanpa ada variabel lain yang memediasi (intervening) hubungan variabel tadi. Hubungan tidak langsung adalah jika ada variabel lain yang memediasi hubungan kedua variabel independen dan dependen.

Agar model regresi menjadi estimator linier yang tidak bias (Best Linier Unbias Estimator/BLUE) maka dilakukan pengujian asumsi klasik terhadap model regresi, yang terdiri dari uji normalitas, multikolinieritas, autokorelasi dan heteroskedastisitas. Untuk menguji hipotesis penelitian digunakan uji signifikansi parsial (uji - t) dan uji sobel.

\section{HASIL DAN PEMBAHASAN}

Untuk memenuhi ketentuan dalam uji asumsi klasik maka semua variabel dalam penelitian ini ditransformasi ke dalam bentuk logaritma natural (Ln). Selanjutnya data penelitian dianalisis dengan regresi linier berganda melalui dua tahap sehingga diperoleh hasil seperti yang tertera pada tabel 1 dan 2 .

Tabel 1. Hasil Analisis Regresi Tahap 1

\begin{tabular}{|c|c|c|c|c|c|}
\hline $\begin{array}{c}\text { Variabel } \\
\text { Terikat }\end{array}$ & $\begin{array}{c}\text { Variabel } \\
\text { Bebas }\end{array}$ & $\begin{array}{c}\text { Standardized } \\
\text { Coefficients } \\
\text { Beta }\end{array}$ & $p$-value & $t$-value & $\mathrm{R}^{2}$ \\
\hline LnHS & LnFCF & 0,576 & 0,000 & 5,366 & \\
& LnDER & $-0,301$ & 0,001 & $-3,494$ & \\
& LnDPR & 0,187 & 0,086 & 1,741 & \\
\hline
\end{tabular}

Sumber: output SPSS

Hasil uji-t menunjukkan bahwa variabel free cash flow berpengaruh positif dan signifikan terhadap harga saham. Hal ini berarti bahwa hipotesis penelitian pertama (H1) diterima. Hal ini mengindikasikan bahwa free cash flow yang tinggi merupakan sinyal positif bagi investor.

Variabel leverage yang diproksikan dengan Debt to Equity Ratio berpengaruh negatif dan signifikan terhadap harga saham. Hal ini berarti bahwa hipotesis penelitian kedua $(\mathrm{H} 2)$ diterima. Hasil penelitian ini mengindikasikan bahwa hutang yang besar dianggap sebagai suatu risiko yang merupakan sinyal negatif bagi investor.

Variabel kebijakan dividen yang diproksikan dengan Dividend Payout Ratio tidak berpengaruh signifikan terhadap harga saham. Hal ini berarti bahwa hipotesis penelitian kelima (H5) ditolak. Hasil penelitian ini menunjukkan bahwa pembayaran dividen tidak direspon oleh pasar, yang berarti sesuai dengan Dividend Irrelevance Theory yang menyatakan bahwa nilai perusahaan tidak ditentukan oleh besar kecilnya pembagian dividen. Hasil penelitian ini juga mengindikasikan bahwa Dividend Signaling Theory tidak dapat mendukung hasil penelitian ini.

Hasil regresi juga menunjukkan nilai $\mathrm{R}^{2}$ sebesar 0,529 , yang berarti bahwa 52,9 persen variabel harga saham dipengaruhi oleh variabel free cash flow, leverage serta Dividend Payout Ratio, dan sisanya dipengaruhi oleh variabel lain diluar model penelitian ini. 
Tabel 2. Hasil Analisis Regresi Tahap 2

\begin{tabular}{|c|l|r|r|r|r|}
\hline $\begin{array}{c}\text { Variabel } \\
\text { Terikat }\end{array}$ & $\begin{array}{c}\text { Variabel } \\
\text { Bebas }\end{array}$ & $\begin{array}{c}\text { Standardized } \\
\text { Coefficients } \\
\text { Beta }\end{array}$ & $p$-value & $t$-value & $\mathrm{R}^{2}$ \\
\hline LnDPR & & & & & 0,372 \\
& LnFCF & 0,601 & 0,000 & 6,108 & \\
& LnDER & 0,055 & 0,575 & 0,564 & \\
\hline
\end{tabular}

\section{Sumber: output SPSS}

Hasil uji-t untuk persamaan regresi yang kedua menunjukkan bahwa variabel free cash flow berpengaruh positif dan signifikan terhadap kebijakan dividen (DPR). Berdasarkan hasil penelitian maka hipotesis penelitian ketiga (H3) diterima. Hasil ini mengindikasikan bahwa ketersediaan aliran kas bebas yang dihasilkan oleh perusahaan berdampak pada peningkatan pembayaran dividen. Variabel leverage (DER) memiliki hubungan positif terhadap Dividen Payout Ratio namun tidak memberikan pengaruh secara signifikan, yang berarti bahwa peningkatan leverage tidak serta merta diikuti oleh peningkatan pembayaran dividen. Berdasarkan hasil penelitian maka hipotesis penelitian keempat (H4) ditolak. Nilai $\mathrm{R}^{2}$ sebesar 0,372 menunjukkan bahwa 37,2 persen variabel kebijakan dividen dipengaruhi oleh variabel free cash flow dan leverage.

\section{Gambar 1. Hasil Diagram Jalur}

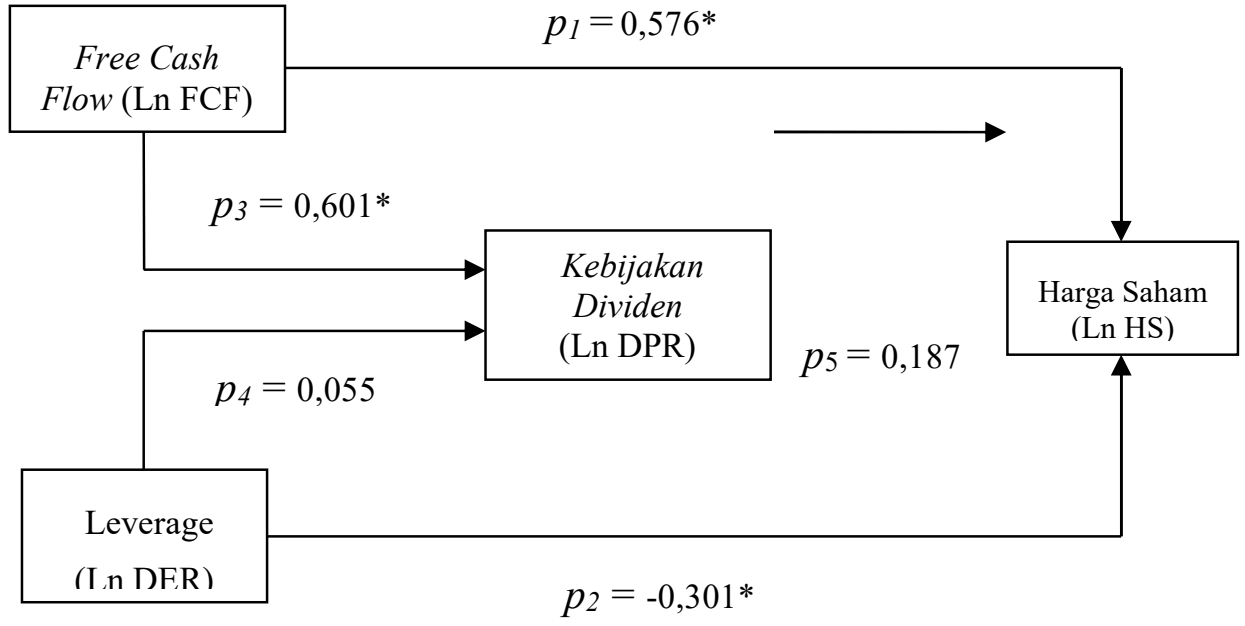

Keterangan Gambar 1 :

* : berpengaruh signifikan dengan $\alpha=0,05$

Tabel 3. Pengaruh Tidak Langsung dan Total

\begin{tabular}{|c|c|c|c|c|c|c|c|}
\hline $\begin{array}{c}\text { Exsogen } \\
\text { Variables }\end{array}$ & $\begin{array}{c}\text { Intervening } \\
\text { Variable }\end{array}$ & $\begin{array}{c}\text { Endogen } \\
\text { Variable }\end{array}$ & $\begin{array}{c}\text { Direct } \\
\text { Effect }\end{array}$ & $\begin{array}{c}\text { Indirect } \\
\text { Effect }\end{array}$ & $\begin{array}{c}\text { Total } \\
\text { Effect }\end{array}$ & $\begin{array}{c}\text { Std. error } \\
\text { inderect effect }\end{array}$ & t-stat. \\
\hline
\end{tabular}


Vol. 1, No. 2 Maret 2016 - Halaman 1 s.d 13

\begin{tabular}{|l|c|c|c|c|c|c|c|}
\hline $\begin{array}{l}\text { Exsogen } \\
\text { Variables }\end{array}$ & $\begin{array}{c}\text { Intervening } \\
\text { Variable }\end{array}$ & $\begin{array}{c}\text { Endogen } \\
\text { Variable }\end{array}$ & $\begin{array}{c}\text { Direct } \\
\text { Effect }\end{array}$ & $\begin{array}{c}\text { Indirect } \\
\text { Effect }\end{array}$ & $\begin{array}{c}\text { Total } \\
\text { Effect }\end{array}$ & $\begin{array}{c}\text { Std. error } \\
\text { inderect effect }\end{array}$ & $t$-stat. \\
\cline { 1 - 1 } $\begin{array}{l}\text { Free Cash } \\
\text { Flow } \\
\text { (FCF) }\end{array}$ & $\begin{array}{c}\text { Kebijakan } \\
\text { Dividen } \\
\text { (DPR) }\end{array}$ & $\begin{array}{c}\text { Harga } \\
\text { Saham } \\
\text { (DER) }\end{array}$ & 0,576 & 0,112387 & 0,688387 & 0,182921752 & 0,614 \\
\cline { 1 - 1 } & & (HS) & $-0,301$ & 0,010285 & $-0,290715$ & 0,028596504 & 0,360 \\
\hline
\end{tabular}

Sumber: output SPSS diolah

Gambar 1 menunjukkan hubungan antar variabel bebas (exsogen variable), variabel terikat (endogen variable) dan variabel intervening dalam penelitian ini, yang juga dilengkapi dengan koefisien jalur. Nilai dari koefisien jalur $p_{1}$ menunjukkan besarnya pengaruh langsung variabel free cash flow terhadap harga saham. Pengaruh langsung dari variabel leverage terhadap harga saham ditunjukkan dengan koefisien jalur $p_{2}$. Pengaruh tidak langsung (koefisien mediasi) dan total pengaruh dari variabel free cash flow dan leverage terhadap harga saham melalui variabel kebijakan dividen dapat dilihat pada tabel 3.

Uji sobel dilakukan untuk menguji signifikansi pengaruh tidak langsung dari variabel bebas terhadap variabel terikat. Dalam uji sobel, nilai t-hitung dari pengaruh tak langsung dibandingkan dengan $t$ tabel. Hasil uji sobel menunjukkan bahwa nilai t-hitung dari pengaruh tidak langsung free cash flow terhadap harga saham lebih kecil dari nilai t-tabel (2,003). Hal ini mengindikasikan bahwa variabel kebijakan dividen tidak dapat memediasi pengaruh free cash flow terhadap harga saham. Hal ini berarti bahwa hipotesis penelitian keenam (H6) ditolak.

Hasil uji sobel juga menunjukkan bahwa nilai t-hitung dari pengaruh tidak langsung leverage terhadap harga saham lebih kecil dari nilai t-tabel $(2,003)$. Hal ini mengindikasikan bahwa variabel kebijakan dividen tidak dapat memediasi pengaruh leverage terhadap harga saham, yang berarti hipotesis penelitian ketujuh (H7) ditolak.

\section{KESIMPULAN DAN SARAN}

\subsection{Kesimpulan} berikut:

Berdasarkan uraian dalam hasil dan pembahasan dapat disimpulkan sebagai

1. Free cash flow berpengaruh positif dan signifikan terhadap harga saham.

2. Leverage berpengaruh negatif dan signifikan terhadap terhadap harga saham.

3. Free cash flow berpengaruh positif dan signifikan terhadap kebijakan dividen.

4. Leverage tidak berpengaruh signifikan terhadap kebijakan dividen.

5. Kebijakan dividen tidak berpengaruh terhadap harga saham.

6. Pengaruh tidak langsung Free cash flow maupun leverage terhadap harga saham melalui kebijakan dividen tidak signifikan, yang berarti bahwa kebijakan dividen tidak dapat memediasi pengaruh tersebut.

\subsection{Saran}

Berdasarkan kesimpulan di atas disarankan beberapa hal sebagai berikut:

1. Bagi pihak manajemen perusahaan agar memperhatikan free cash flow dan leverage karena hasil penelitian ini menunjukkan bahwa free cash flow berpengaruh terhadap harga saham dan kebijakan dividen sedangkan leverage 
berpengaruh terhadap harga saham. Namun pihak manajemen juga harus berhati-hati dalam penggunaan leverage karena hal ini berpengaruh negatif terhadap harga saham.

2. Bagi peneliti selanjutnya diharapkan untuk meneliti pengaruh variabel lainnya terhadap harga saham maupun kebijakan dividen. Hal ini karena rendahnya koefisien determinasi dalam penelitian ini, yang berarti bahwa terdapat variabel lain di luar peneltian ini yang mempengaruhi harga saham dan kebijakan dividen.

\section{DAFTAR PUSTAKA}

Arieska, Metha dan Barbara Gunawan. 2011. Pengaruh Aliran Kas Bebas dan Keputusan Pendanaan Terhadap Nilai Pemegang Saham dengan Set Kesempatan Investasi dan Dividen Sebagai Variabel Moderasi. Jurnal Akuntansi Dan Keuangan, Vol. 13, No. 1, hal. 13-23.

Atmaja, Lukas Setia. 2008. Teori dan Praktik Manajemen Keuangan. Yogyakarta: Penerbit ANDI.

Brigham, Eugene F. dan Houston, Joel F. 2006. Fundamentals of Financial Management. Tenth Edition, Buku I. Terjemahan dari: Ali Akbar Yulianto. Jakarta: Salemba Empat.

Brigham, Eugene F dan Philip R. Daves. 2004. Intermediate Financial Management - International Student Edition. $8^{\text {th }}$ Edition. USA: Thomson South-Western.

Embara, Cecilia Triana Dewi Lestari, Ni Luh Putu Wiagustini dan Ida Bagus Badjra. 2012. Variabel-Variabel Yang Berpengaruh Terhadap Kebijakan Dividen Serta Harga Saham Pada Perusahaan Manufaktur Di Bursa Efek Indonesia. Jurnal Manajemen, Strategi Bisnis, dan Kewirausahaan Vol. 6, No. 2.

Ghozali, Imam. 2012. Aplikasi Analisis Multivariate Dengan Program IBM SPSS 20, Edisi Keenam. Semarang: Badan Penerbit Universitas Diponegoro.

Lucyanda, Jurica \& Lilyana. 2012. Pengaruh Free Cash Flow dan Struktur Kepemilikan Terhadap Dividend Payout Ratio. Jurnal Dinamika Akuntansi 4 (2), hal: 129-138.

Mahaputra, Gede Agus dan Ni Gusti Putu Wirawati. 2014. Pengaruh Faktor Keuangan Dan Ukuran Perusahaan Pada Dividend Payout Ratio Perusahaan Perbankan. E-Jurnal Akuntansi Universitas Udayana Vol. 9 No. 3, hal. 695 708.

Mardasari, Rizky Budi. 2014. Pengaruh Insider Ownership, Kebijakan Hutang Dan Free Cash Flow Terhadap Nilai Perusahaan Melalui Kebijakan Dividen. Jurnal Ilmu Manajemen Volume 2 Nomor 4, hal. 1807 - 1820.

Parsian, Hosein and Amir Shams Koloukhi. 2014. A study on the effect of free cash flow and profitability current ratio on dividend payout ratio: Evidence from Tehran Stock Exchange. Management Science Letters vol. 4 (2014), pp. 63-70. www.GrowingScience.com/msl.

Riyanto, Bambang. 2001. Dasar-dasar Pembelanjaan Perusahaan. Yogyakarta : BPFE

Rizqia, Dwita Ayu, Siti Aisjah dan Sumiati. 2013. Effect of Managerial Ownership, Financial Leverage, Profitability, Firm Size, and Investment Opportunity on 
Vol. 1, No. 2 Maret 2016 - Halaman 1 s.d 13

Dividend Policy and Firm Value. Research Journal of Finance And Accounting, 4 (11): 120-130.

Safkaur, Otniel. 2015. The Analysis Impact of Agency Cost and Transaction Cost To Dividend. Research Journal of Finance and Accounting vol. 6 no.6, pp. 133142.

Sartono, Agus. 2001. Manajemen Keuangan Teori dan Aplikasi, Edisi 4. Yogyakarta: BPFE.

Setiabudi, Andy dan Dian Agustia. 2012. Fundamental Faktor of Firm Due to The Firm Value. Journal of Basic and Applied Scientific Research vol. 2 (12), pp. 12651-12659.

Sugiyono. 2013. Metode Penelitian Bisnis, Edisi Pertama. Alfabeta: Bandung.

Wardani, R.A.Kusuma dan Baldric Siregar. 2009. Pengaruh Aliran Kas Bebas Terhadap Nilai Pemegang Saham Dengan Set Kesempatan Investasi dan Dividen Sebagai Variabel Moderator. Jurnal Akuntansi dan Manajemen. Vol. 20. No. 3 Desember, hal. 157-174.

Wati, Ni Kadek Ari Lina dan Ni Putu Ayu Darmayanti. 2012. Pengaruh Kepemilikan Manajerial dan Kinerja Keuangan terhadap Kebijakan Dividen dan Nilai Perusahaan. Jurnal Ilmiah Akuntansi dan Bisnis Vol. 2 (12), hal. 103-124.

Weston, J. Fred dan Thomas E. Copeland. 1996. Manajemen Keuangan. Jilid Satu, Edisi Kesembilan, Terjemahan oleh Jaka Wasana dan Kibrandoko, 1997. Jakarta: Bina Rupa Aksara.

Zakaria, Zuriawati, Joriah Muhammad dan Abdul Hadi Zulkifli. 2012. The Impact of Dividend Policy on the Share Price Volatility (Malaysian Construction and Material Companies). International Journal of Economics and Management Sciences, Vol. 2, No. 05, pp. 01-08.

www.idx.co.id

www.sahamok.com 